\title{
ROD-ON-ROD TAYLOR TESZT MODELLEZÉSE
}

\section{MODELING OF A ROD-ON-ROD TAYLOR TEST}

\author{
Gonda Viktor, Varga Péter \\ Óbudai Egyetem, Bánki Donát Gépész és Biztonságtechnikai Mérnöki Kar, 1081 \\ Budapest, Népszínház u. 8. Tel. +36-1-666-5310,gonda.viktor@bgk.uni-obuda.hu
}

\begin{abstract}
Symmetric rod-on-rod Taylor testing is applied for the determination of high strain rate mechanical properties. The deformation of the specimen is highly complex in this testing method. We examined the evolution of the deformation and temperature in copper specimen by using a coupled thermomechanical finite element simulation for three different impact velocities.
\end{abstract}

Keywords: Taylor impact test, rod-on-rod, Johnson-Cook materials model, finite element method.

\section{Összefoglalás}

Az extrém nagy alakváltozási sebességü mechanikai vizsgálat egyik módja a szimmetrikus elrendezésű, rod-on-rod Taylor ütközési vizsgálat. Az alakváltozás lefolyása igen komplex a próbatestekben. A deformáció és hőmérséklet kialakulását csatolt termo mechanikus véges elemes modellel vizsgáltuk vörösréz próbatestekben, három különböző sebességü becsapódás esetén.

Kulcsszavak: Taylor teszt, rod-on-rod, Johnson-Cook anyagmodell, véges elemes módszer.

\section{Bevezetés}

Fémes szerkezeti anyagok nagy sebességü és nagymértékü alakváltozása létrejöhet lövedékek becsapódásakor, jármüvek ütközésekor, vagy nagy sebességü képlékeny alakításkor pl. robbantásos vagy elektrodinamikus alakításkor. Ilyenkor a képlékeny alakváltozási sebesség mértéke $>10^{3} \mathrm{~s}^{-1}$ nagyságrendü is lehet. Az anyag makro deformációját a tömeghatás, az alakítási keményedés, a sebesség-érzékenység, valamint a képlékeny alakváltozás miatt kialakuló hőmérséklet-emelkedéssel járó lágyulás határozza meg. Az ún. Taylor ütközési vizsgálattal [1,2] egy hengeres alakú próbatestet egy falnak lövünk, a deformált geometriából becsülhető a dinamikus alakítási szilárdság. Ennek a vizsgálatnak egy változata, amikor egy próbatestet egy falnak megtámasztott próbatestnek lövünk, az ún. rod-on-rod Taylor teszt (RNR), vagy szimmetrikus Taylor teszt [3, 4]. A próbatest alakváltozásának modellezéséhez olyan anyagmodellt választhatunk, ami a nagy alakváltozási sebesség tartományban is jól írja le az anyagi viselkedést, a JohnsonCook modellt [5].

Ebben a dolgozatban egy réz próbatest rod-on-rod Taylor tesztjének véges elemes szimulációját mutatjuk be. Az anyagmodell a Johnson-Cook modell, három becsapódási sebesség esetén vizsgáljuk az ütközést, melyek értékeinél már képlékeny alakváltozás is létrejön, de képlékeny tönkremenetel még nem. Vizsgáltuk a 
képlékeny alakváltozás hatására kialakuló felhevülés okozta lágyulás hatását a kialakuló deformációra.

\section{Modellezés}

A rod-on-rod Taylor teszt végeselemes szimulációját az MSC Marcban hoztuk létre. Mindkét hengeres próbatest kiinduló átméröje 7,62 $\mathrm{mm}$, a hosszuk $l_{0}=25,4 \mathrm{~mm}$. A tengelyszimmetriát kihasználva síkbeli modellt készítettünk egy sugárnyi szélességgel. A hálót az érintkezési vonal (felület) irányába finomítottuk. A próbatest becsapódási sebessége $(v): 130 \mathrm{~m} / \mathrm{s} ; 190$ $\mathrm{m} / \mathrm{s}$; vagy $250 \mathrm{~m} / \mathrm{s}$ volt. A falat merevnek és súrlódásmentesnek tekintettük valamint a próbatestek közötti érintkezési felületet is súrlódásmentesnek vettük.

A próbatest anyagára lineárisan rugalmas-képlékeny modellt használtunk. A rugalmassági paraméterek értékei: rugalmassági modulus: $110 \mathrm{GPa}$; Poissontényező: 0,33 . A képlékeny anyagmodellre a Johnson-Cook modellt választottuk [5]:

$$
k_{f}=\left(A+B \varepsilon_{e q}^{n}\right)\left(1+C \cdot \ln \frac{\dot{\varepsilon}_{e q}}{\dot{\varepsilon}_{0}}\right)\left(1-\left(\frac{T-T_{r}}{T_{m}-T_{r}}\right)^{m}\right)
$$

ahol $k_{f}$ az alakítási szilárdság, $\varepsilon_{e q}$ az egyenértékü alakváltozás, az $\dot{\varepsilon}_{e q}$ az egyenértékü alakváltozási sebesség. Az anyagmodell paraméterei rézre vonatkozóan: $A=90 \mathrm{MPa} ; B=292 \mathrm{MPa}$; $n=0,31 ; C=0,025 ; m=1,09 ; \dot{\varepsilon}_{0}=11 / \mathrm{s}$; $T_{r}=300 \mathrm{~K}$ [1]. A modellből számított folyási görbék $300 \mathrm{~K}$ és $600 \mathrm{~K}$ hőmérsékleten, valamint $1 \frac{1 / \mathrm{s}}{\mathrm{s}}$ és $10^{5} \quad 1 / \mathrm{s}$ alakváltozási sebesség értékekhez az 1. ábrán láthatók.

A réz további felhasznált fizikai paraméterei: olvadáspont: $T_{m}=1356 \mathrm{~K}$; sürüség: $8960 \mathrm{~kg} / \mathrm{m}^{3}$; fajlagos hőkapacitás: $383 \mathrm{~J} \cdot \mathrm{kg}^{-1} \cdot \mathrm{K}^{-1}$; hövezetési tényező: 401 $\mathrm{W} \cdot \mathrm{m}^{-1} \cdot \mathrm{K}^{-1}$; hőtágulási tényező: $16,6 \mathrm{ppm} / \mathrm{K}$.
A számítási modell csatolt termomechanikai (TM) esetre futtattuk le, dinamikus tranziens (explicit) megoldóval, a single step Houbolt eljárást használva, a nagy alakváltozás opciót beállítva. Az időlépést a modál analízisből kivett 2 . sajátfrekvencia értékét felhasználva határoztuk meg, majd ezt finomítottuk, $10^{-7}$ s körüli értéken.

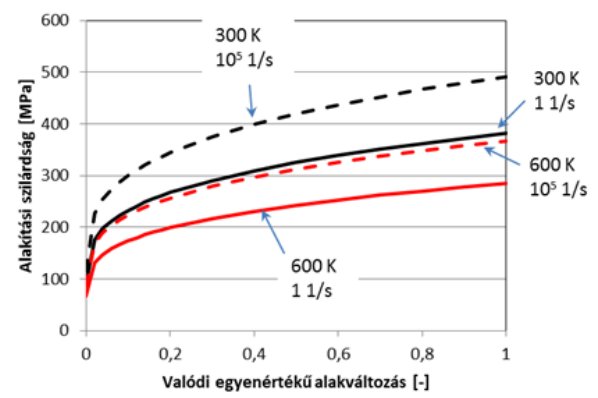

1. ábra. A réz folyási görbéi a Johnson-Cook modellböl számitva.

\section{Eredmények és következtetések}

A próbatestek alakváltozását $250 \mathrm{~m} / \mathrm{s}$ ütközési sebességnél az ütközés után 240 $\mu$ s-al ábrázoltuk a 2. ábrán. A színezés az egyenértékủ maradó alakváltozást jelöli. Összehasonlítva a klasszikus Taylor teszt eredményeivel [2], a rod-on-rod tesztnél azonos becsapódási sebességnél kisebb a létrejövő deformáció [4]. A 2. ábrán látható esetre a legnagyobb maradó alakváltozás értéke 1 körüli, még a klasszikus esetben ez az érték már $130 \mathrm{~m} / \mathrm{s}$-os becsapódási sebességnél létrejön a próbatestben, és 190 $\mathrm{m} / \mathrm{s}$-nál már 2 fölötti alakváltozást is elérjük [2]. A klasszikus teszthez $190 \mathrm{~m} / \mathrm{s}$ fölötti becsapódási sebességekhez nem futtattunk szimulációt, ui. ekkor képlékeny tönkremenetel jön létre [4]. A 2. ábrán a próbatestek alakját megfigyelve elmondható, hogy a szimmetrikus Taylor tesztben a próbatestek deformációja nem szimmetrikus, az ütközést felvevő álló próbatest nagyobb térfogatban alakváltozik, mint a becsapódó próbatest, de maximális 
alakváltozás értéke közel azonos mindkét próbatestben.

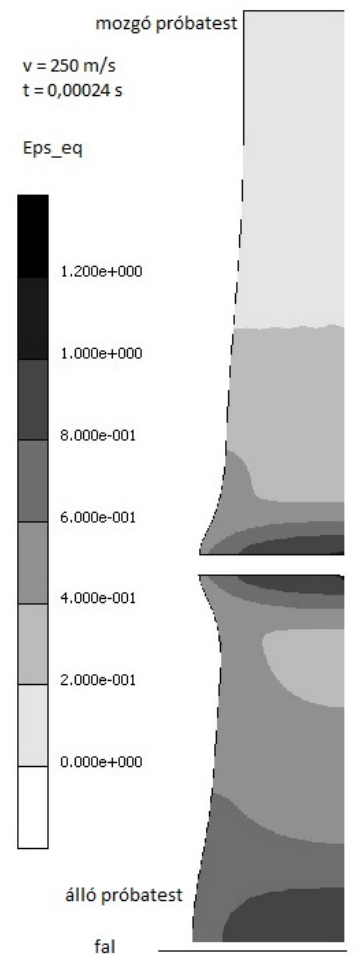

2. ábra. A próbatestek alakváltozása $250 \mathrm{~m} / \mathrm{s}$ ütközési sebességnél az ütközés után $240 \mu s-a l$. A skála az egyenértékü maradó alakváltozást jelöli.

Az alakváltozások eloszlása a próbatestekben a szimmetriatengelyen mentén a különböző ütköző becsapódási sebességek esetén a 3. ábrán látható. A legnagyobb egyenértékü maradó alakváltozások értékei kb. 0,3;0,6; és 1 a 130, 190 és $250 \mathrm{~m} / \mathrm{s}-$ os becsapódási sebességekhez. A két próbatest közti érintkező felületen $(0,025 \mathrm{~m}) \quad \mathrm{a}$ szimmetriatengelyen lévő csomópontban az alakváltozások értékei irreális mértékben megugranak a numerikus számításban.

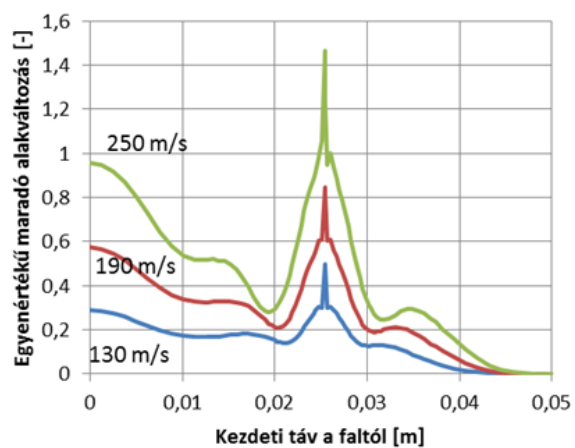

3. ábra. Az egyenértékü maradó alakváltozás a szimmetriatengelyen a faltól való kezdeti távolság függvényében, 130, 190 és $250 \mathrm{~m} / \mathrm{s}$ ütközési sebességnél az ütközés után $240 \mu$ s-al. A próbatestek érintkezö felülete 0,025 m-nél található.

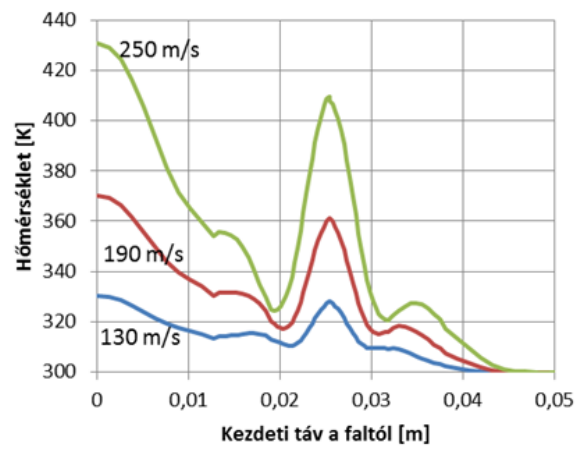

4. ábra. A hömérséklet eloszlása a szimmetriatengelyen a faltól való kezdeti távolság függvényében, 130, 190 és $250 \mathrm{~m} / \mathrm{s}$ ütközési sebességnél az ütközés után $240 \mu s-a l$. A próbatestek érintkezö felülete 0,025 m-nél található.

A TM modellben a létrejövő legnagyobb hőmérsékletemelkedés a próbatestekben $30 ; 70$; illetve $130{ }^{\circ} \mathrm{C}$ a 130 ; 190; valamint $250 \mathrm{~m} / \mathrm{s}-$ os becsapódási sebességekhez (4. ábra). A felvevő próbatest fallal érintkező részén alakul ki a legnagyobb hőmérsékletemelkedés, a két próbatest közti érintkező felületen $5-20{ }^{\circ} \mathrm{C}$ kal kisebb a hőmérsékletemelkedés. 
A klasszikus Taylor teszt esetén a hőmérsékletnövekedés értékei jóval nagyobbak: 160 ; 190 ; és $340^{\circ} \mathrm{C}$ a $130 ; 144$; és $190 \mathrm{~m} / \mathrm{s}-$ os becsapódási sebességekhez számítva [2].

A hőmérséklet eloszlásokat vizsgálva látható, hogy a nagy hőmérsékletnövekedés egyrészt a próbatestek egymással ütköző felületéhez közeli $-\mathrm{kb}$. 5 mm-es tartományban alakul ki, valamint a felvevő próbatest fallal érintkező felületénél kb. 10 mm-es tartományban. A hőmérsékletemelkedés lágyulást okoz, ezáltal kisebb ellenállást a további alakváltozásnak, de jelentősebb mértékű lágyulás csak a legnagyobb ütközési sebességnél következik be a rod-on-rod tesztnél.

Az alakváltozások szimmetriatengelyen vett eloszlását három deformációs tartomány különböztethetö meg: a becsapódó próbatesten a becsapódáshoz közeli (0-5 mm) nagy alakváltozási rész, kis képlékeny alakváltozó rész, valamint a maradó alakváltozást nem szenvedő rész, itt csak rugalmas alakváltozások jönnek létre. A felvevő próbatesten az érintkező felületek közelében nagy alakváltozó részeket találunk, a közbezárt hosszon közepes méretű alakváltozási zónát.

A falban ébredő erőt az idő függvényében ábrázoltuk az 5 . ábrán a három becsapódási sebességhez. $\mathrm{Az}$ erő értéke viszonylag lassan fut fel a becsapódás első szakaszában, amikor a próbatestek alakváltozása és felkeményedése megtörténik, majd a maximális erő elérése után hirtelen visszaesik, amikor a próbatestek visszapattannak, az ütközés utáni sebességük kb. a becsapódási sebesség 10\%-a. A képlékeny alakváltozás időtartama 120-150 $\mu$ s.
A visszapattanás után a nagy, képlékeny alakváltozást okozó nyomófeszültség lecsengése után komplex módusú rugalmas lengés alakul ki a próbatestekben.

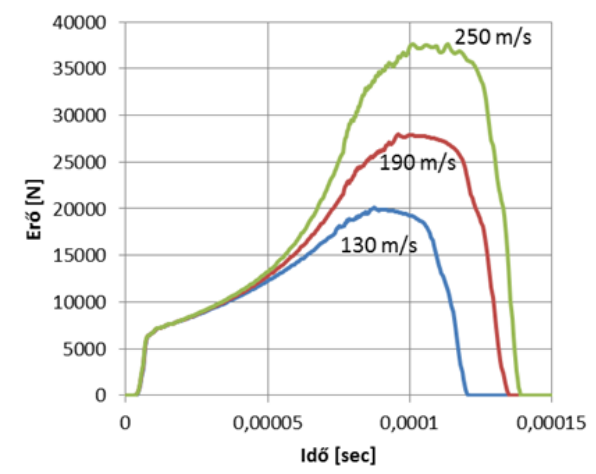

5. ábra. A falban ébredö erő az idö függvényében 130, 190 és $250 \mathrm{~m} / \mathrm{s}$ ütközési sebességnél.

\section{Köszönetnyilvánítás}

A dolgozat a Bolyai János Kutatási Ösztöndíj támogatásával készült.

\section{Szakirodalmi hivatkozások}

[1] Taylor, G. I.: The testing of materials at high rates of loading, J. Inst. Civil Eng. 26, 1946. 486-519.

[2] Varga Péter, Gonda Viktor, Rácz Pál: Taylor teszt modellezése a Johnson-Cook anyagmodell felhasználásával: a hömérséklet hatása. FMTÜ XX. pp. 327-330., 2015.

[3] L.C. Forde, W. G. Proud, S.M. Walley: Symmetrical Taylor impact studies of copper. Proc. R. Soc. A 465, pp. 769-790, 2009.

[4] G. Iannitti, N. Bonora, A. Ruggiero, G. Testa: Ductile damage in Taylor-anvil and rod-on-rod impact experiment. IOP J. of Physics: Conf. Series 500, 112035, 2014.

[5] Johnson, G.R., Cook, W.H.: A constitutive model and data for metals..., Proc. 7th Int. symp. on Ballistics, The Netherlands, 1983. 541-547. 